\title{
POTRZEBY ZDROWOTNE REALIZOWANE PRZEZ AKTYWNOŚĆ FIZYCZNĄ OSÓB STARSZYCH
}

\section{HEALTH NEEDS SATISFIED BY PHYSICAL ACTIVITY IN THE ELDERLY}

\author{
Zofia Kubińska $^{1(\mathrm{~A}, \mathrm{~B}, \mathrm{E}, \mathrm{F})}$, Anna Pańczuk ${ }^{1(\mathrm{C}, \mathrm{D}, \mathrm{E})}$
}

${ }^{1}$ Zakład Fizjoterapii, Katedra Kultury Fizycznej i Fizjoterapii, Państwowa Szkoła Wyższa im. Papieża Jana Pawła II w Białej Podlaskiej

Kubińska, Z., Pańczuk, A. (2018). Potrzeby zdrowotne realizowane przez aktywność fizyczną osób starszych. Rozprawy Społeczne, 12(1), 73-79. https://doi.org/10.29316/rs.2018.09

Wkład autorów:

A. Zaplanowanie badań

B. Zebranie danych

C. Dane - analiza i statystyki

D. Interpretacja danych

E. Przygotowanie artykułu

F. Wyszukiwanie i analiza

literatury

G. Zebranie funduszy
Tabele: 1

Ryciny: 2

Literatura: 41

Otrzymano: kwiecień 2017

Zaakceptowano: maj 2017

\section{Streszczenie}

Wstęp. W latach 90. eksperci stwierdzili, że w strategii zdrowia publicznego zwiększenie aktywności fizycznej społeczeństwa jest równie istotne jak leczenie nadciśnienia tętniczego, zaburzeń przemiany lipidowej czy walka z nałogiem palenia tytoniu (Drygas, Jagier, 2003). Celem pracy było przedstawienie rodzajów potrzeb zdrowotnych osób starszych zaspokajanych przez podejmowaną aktywność fizyczną z uwzględnieniem stopnia ich realizacji.

Materiał i metody. Badania przeprowadzono w 2016 roku wśród mieszkańców powiatu bialskiego i okolic (północna część województwa lubelskiego). Przebadano 221 osób w wieku 6090 lat. Wśród badanych przeważały kobiety $(65,6 \%)$ oraz mieszkańcy wsi $(56,9 \%)$. W pracy zastosowano metodę sondażu diagnostycznego z wykorzystaniem autorskiego kwestionariusza ankiety.

Wyniki. Najliczniejsza grupa badanych seniorów wskazała, iż przez podejmowaną aktywność fizyczną realizuje potrzeby prorodzinne $(92,3 \%)$, profilaktyczne $(91,9 \%)$, ruchu $(89,1 \%)$ oraz antyinwolucyjne i aktywności turystycznej (po 88,7\%). Najmniej liczna grupa badanych realizuje potrzeby aktywnej niepełnosprawności $(69,2 \%)$ oraz rehabilitacyjne $(77,8 \%)$.

Wnioski. Badani seniorzy, przez aktywność fizyczną, realizowali wszystkie analizowane potrzeby zdrowotne. Najliczniejsza grupa realizowała potrzeby prorodzinne, profilaktyczne, ruchu, antyinwolucyjne oraz aktywności turystycznej. W największym stopniu zaspokajane były potrzeby prorodzinne, profilaktyczne oraz ruchu, natomiast w najmniejszym potrzeby aktywnej niepełnosprawności i rekreacji ruchowej.

Słowa kluczowe: osoby starsze, potrzeby zdrowotne, aktywność fizyczna

\section{Summary}

Introduction. In the 1990s, experts stated that, with regard to the public health strategy, increasing physical activity in society is as significant as treatment of hypertension, lipid metabolism disorders or battles against tobacco addiction (Drygas, Jagier, 2003). The purpose of the paper was to present types of health needs of the elderly, which are met by undertaking physical activity, with further consideration of the degree of its implementation.

Material and method. The research was conducted in 2016 among the residents of Biała Podlaska district and the surrounding area (northern part of the Lublin Province). Altogether, 221 persons aged 60-90 were examined. The majority of the respondents were women (65.6\%) and rural residents $(56.9 \%)$. The paper applies the method of the diagnostic survey with the use of the author's own survey questionnaire.

Results. The most numerous group of the surveyed seniors indicated that the undertaken PA satisfies the following needs: family-related (92.3\%), prophylactic (91.9\%), movement $(89.1 \%)$, as well as anti-involutionary and tourism-related (both $88.7 \%)$. The fewest indications were given to the need of becoming active in case of disability (69.2\%) and rehabilitation (77.8\%). Conclusions. Physical activity helped the surveyed seniors to satisfy all of the analysed health needs. The respondents would mainly point to family-related needs, preventive ones, movement, anti-involutionary as well as tourist and activity-related ones. The needs that seemed most fulfilled were family-related, prophylactic and those concerning movement while preventing active disability and physical recreation were met the least.

Keywords: the elderly, health needs, physical activity

Adres korespondencyjny: Zofia Kubińska, Państwowa Szkoła Wyższa im. Papieża Jana Pawła II w Białej Podlaskiej, Zakład Fizjoterapii, ul. Sidorska 105, 21-500 Biała Podlaska, e-mail: zofiakubinska@wp.pl, tel.: 833449902

Copyright by: Państwowa Szkoła Wyższa im. Papieża Jana Pawła II w Białej Podlaskiej, Zofia Kubińska, Anna Pańczuk

Czasopismo Open Access, wszystkie artykuły udostępniane są na mocy licencji Creative Commons Uznanie autorstwa-użycie niekomercyjne-na tych samych warunkach 4.0 Międzynarodowe (CC BY-NC-SA 4.0, http://creativecommons.org/licenses/by-nc-sa/4.0/). 


\section{Wstęp}

Liczne badania dowiodły, że odpowiednie zaspokajanie potrzeby aktywności fizycznej przez osoby starsze, narażone na wiele deficytów zdrowotnych, należy do bardzo ważnych, naturalnych zachowań zdrowotnych. W latach 90-tych eksperci stwierdzili, że w strategii zdrowia publicznego zwiększenie aktywności fizycznej społeczeństwa jest równie istotne jak leczenie nadciśnienia tętniczego, zaburzeń przemiany lipidowej czy walka z nałogiem palenia tytoniu (Drygas, Jagier, 2003; Jegier, Stasiołek, 2001; Osiński, 2013; Rottermund, Knapik, Szyszka, 2015; Grzanka-Tykwińska, Kędziora-Kornatowska, 2010; Ignasiak i in., 2011; Kozdroń, 2012; Ainsworth, Jacobs, Leon, 1993; Makuła, 2012; Wieczorkowska-Tobis, Kostka, Borowicz, 2011).

Szeroki zakres potrzeb zdrowotnych i życiowych osób starszych w interdyscyplinarnym ujęciu poznaliśmy w Europejskim Roku Aktywności Osób Starszych i Solidarności Międzypokoleniowej dzięki licznym, naukowym inicjatywom (Ministerstwo Pracy i Polityki Społecznej, 2013; Błędowski, Szatur-Jaworska, Szweda-Lewandowska, Kubicki, 2012; Mossakowska, Więcek, Błędowski, 2012; Zdziarski, 2015). W raportach i innych pracach naukowych wielokrotnie potwierdzano zdrowotną rolę aktywności fizycznej w starzeniu. W literaturze przedmiotu występuje ona jako istotna składowa stylu życia, czyli zachowanie zdrowotne, nad którym każdy człowiek ma największą kontrolę (Żołnierczuk-Kieliszek, 2014; Osiński, 2013; Drabik, Resiak, 2010; Woynarowska, 2008). Zachowania zdrowotne to wszelkie formy aktywności celowej, ukierunkowanej na ochronę lub osiągnięcie poprawy własnego zdrowia. Wynikają one z indywidualnej troski o własne zdrowie i są niezależne od funkcjonującego systemu opieki zdrowotnej (Syrek, 2000; Majchrowska, 2003; Słopiecka, Cieślik, 2011).

Według Drygasa i in. nie do przecenienia jest pozytywny, chociaż ciągle niedoceniany, wpływ aktywności fizycznej na funkcjonowanie organizmu osób w wieku starszym i zjawisko tzw. pomyślnego starzenia się. Regularna aktywność fizyczna wpływa korzystnie na sprawność umysłową i stanowi czynnik ochronny przed zaburzeniami pamięci. W innym miejscu autorzy podkreślają, że wysiłek fizyczny jest czynnikiem ochronnym, niezależnym od uwarunkowań genetycznych oraz biologicznych i socjoekonomicznych czynników ryzyka (Drygas, Piotrowicz, Jegier, Kopeć, Podolec, 2010). Kostka (2010) zwraca uwagę, że aktywność fizyczna jest lekiem wykorzystywanym w profilaktyce i leczeniu chorób istotnie związanych $\mathrm{z}$ wiekiem tj. choroba wieńcowa, nadciśnienie tętnicze, otyłość, hipercholesterolemia, cukrzyca, osteoporoza. Stwierdził też, że „aktywność ruchowa jest najważniejszym determinantem braku niepełnosprawności w zaawansowanej starości" (s. 456), co wcześniej potwierdziły badania Leveille i in. (Leveille, Guralnik, Ferrucci, Langiois, 1999). Wysiłek fizyczny może być uznany za wspólny mianownik wszystkich działań prewencyjno-rehabilitacyjnych, niezależnie od stanu zdrowia i sprawności fizycznej pacjenta w starszym wieku (Kostka, 2010). Potwierdzają to wcześniejsze badania Lampinen i in. (2006). Innymi istotnymi korzyściami umiarkowanej aktywności fizycznej osób starszych są możliwość wzmocnienia sił odpornościowych organizmu (Terra Sílvia, Gonçalves da Silva, Salerno Pinto, Lourenço Dutra, 2012; Pedersen, Hoffman-Goetz, 2000) oraz lepsze funkcjonowanie poznawcze (Gajos i in., 2014).

Światowa Organizacja Zdrowia (WHO) definiuje potrzeby zdrowotne jako „zakłócenia w stanie zdrowia lub samopoczuciu społecznym, które wymagaja interwencji w postaci działań leczniczych, rehabilitacyjnych lub pomocy społecznej, a także działań zapobiegawczych" (za Topór-Mądry, Gilis-Januszewska, Kurkiewicz, Pająk, 2002, s. 15). Zgodnie z koncepcją potrzeb życiowych A. Maslova, potrzeby zdrowotne charakteryzują się tym, że ich niezaspokojenie powoduje chorobę, ich zaspokojenie zapobiega chorobie, ich przywrócenie leczy chorobę, natomiast nie są aktywne ani odczuwane przez osobe zdrową (za Topór-Mądry i in., 2002). W klasyfikacji potrzeb zdrowotnych wg Brandshawa wyróżnia się: potrzebę normatywna, określaną przez ekspertów lub lekarzy; potrzebę odczuwana, która jest utożsamiana z życzeniem określonego świadczenia zdrowotnego; potrzebe wyrażona, która jest potrzebą odczuwana, przekształconą w działanie; potrzebę porównawcza, która może mieć znaczenie planistyczne, odnoszące się do alokacji zasobów opieki zdrowotnej (za Suchecka, 2010; Zarzeczna-Baran, 2010).

W aktualnym raporcie stanu zdrowia i określonych potrzeb zdrowotnych mieszkańców województwa lubelskiego, potrzeby zdrowotne określono w dwóch aspektach: jako zakłócenia zdrowia, oraz jako oddziaływania zmniejszające lub likwidujace te zakłócenia. Aktywność fizyczna jako oddziaływanie leczniczo-profilaktyczne, zmniejszające lub likwidujace zakłócenia zdrowia jest zalecana przez ekspertów jako potrzeba zdrowotna w programach zapobiegania chorobom układu krążenia, ograniczania wysokiej zapadalności na choroby nowotworowe, wczesnego wykrywania cukrzycy, utrzymania prawidłowej masy ciała, zapobiegania negatywnym skutkom schorzeń układu mięśniowo-szkieletowego (Florek-Łuszczki i in., 2015).

Celem pracy było przedstawienie potrzeb zdrowotnych osób starszych zaspokajanych przez podejmowaną aktywność fizyczną z uwzględnieniem stopnia ich realizacji.

\section{Materiał i metody}

Badania przeprowadzono w 2016 roku wśród mieszkańców powiatu bialskiego i okolic (północna część województwa lubelskiego). Przebadano 221 osób w wieku 60-90 lat $(\widetilde{X}-69,9)$. Wśród badanych przeważały kobiety $(65,6 \%)$ oraz mieszkańcy wsi $(56,9 \%)$. 
W badaniach wykorzystano autorski kwestionariusz ankiety. Zawierał on metryczkę (płeć, wiek, miejsce zamieszania) oraz pytania dotyczące stopnia realizacji jedenastu potrzeb zdrowotnych poprzez podejmowaną obecnie aktywność fizyczną. Uwzględnione $\mathrm{w}$ analizie potrzeby zdrowotne wyszczegól- niono na podstawie literatury przedmiotu (Osiński, 2013; Drygas, Jagier, 2003; Drygas i in., 2010; Kostka, 2010; Kozdroń, 2012; Wieczorowska-Tobis i in., 2011; Zdziarski, 2015), a ich ogólną charakterystykę zamieszczono w tabeli 1.

Tabela 1. Rodzaje potrzeb zdrowotnych zaspokajanych przez aktywność fizyczną (opracowanie własne na podstawie literatury)

\begin{tabular}{|c|c|}
\hline Potrzeby zdrowotne & Opis \\
\hline Potrzeba aktywności turystycznej & $\begin{array}{l}\text { AF umożliwiająca kontakt z otoczeniem przyrodniczym, kulturowym, budująca zaso- } \\
\text { by odpornościowe i poznawcze. Potrzeba podejmowana i realizowana dobrowolnie. }\end{array}$ \\
\hline $\begin{array}{l}\text { Potrzeba aktywnej } \\
\text { niepełnosprawności }\end{array}$ & $\begin{array}{l}\text { AF osób z niepełnosprawnością, zwiększająca samodzielność i aktywność społecz- } \\
\text { ną. Zalecana przez lekarza, realizowana przez fizjoterapeutę, rodzinę, opiekuna. }\end{array}$ \\
\hline Potrzeba antyinwolucyjna & $\begin{array}{l}\text { AF opóźniająca procesy starzenia, spadek wydolności, sprawności fizycznej, deficy- } \\
\text { ty biologiczne, psychiczne i społeczne. Podejmowana dobrowolnie. }\end{array}$ \\
\hline Potrzeba funkcjonalno-czynnościowa & $\begin{array}{l}\text { AF po chorobie, urazie, operacji, przywracająca umiejętność lokomocji, samodziel- } \\
\text { nego funkcjonowania. Zalecana przez lekarza, fizjoterapeutę. }\end{array}$ \\
\hline Potrzeba medyczna & AF zalecana przez lekarza w chorobie lub rekonwalescencji. \\
\hline Potrzeba profilaktyczna & $\begin{array}{l}\text { AF zapobiegająca (minimalizująca) schorzeniom, chorobom, niepełnosprawności. } \\
\text { Podejmowana samodzielnie, dobrowolnie. }\end{array}$ \\
\hline Potrzeba prorodzinna & $\begin{array}{l}\text { AF umożliwiająca kontakty, relacje rodzinne, wspólne świętowanie, aktywność wolnocza- } \\
\text { sową, zabawy ruchowe, wysiłek fizyczny z wnukami, dziećmi, mężem, żoną, prace fizycz- } \\
\text { ne, wspieranie w chorobie, kryzysach. Potrzeba podejmowana, realizowana dobrowolnie. }\end{array}$ \\
\hline Potrzeba rehabilitacyjna & $\begin{array}{l}\text { AF zalecana przez lekarza, przywracająca utracone (po chorobie, wypadku) funkcje. } \\
\text { Realizowana przez fizjoterapeutę, rehabilitanta, masażystę. }\end{array}$ \\
\hline Potrzeba rekreacji ruchowej & $\begin{array}{l}\text { AF wolnoczasowa i dobrowolna umożliwiająca regenerację, relaksację po zmęcze- } \\
\text { niu fizycznym, psychicznym, społecznym, dostarczająca przyjemnych wrażeń. }\end{array}$ \\
\hline Potrzeba rewitalizacji & $\begin{array}{l}\text { AF zwiększająca żywotność ustroju, witalność organizmu, usprawniająca procesy } \\
\text { życiowe (fizyczne, umysłowe), dodająca życia do lat. Podejmowana samodzielnie. }\end{array}$ \\
\hline Potrzeba ruchu & $\begin{array}{l}\text { AF w samodzielnym, świadomym praktykowaniu zdrowego stylu życia, oparta na } \\
\text { wiedzy i doświadczeniach, dająca poczucie wartości i dbałości o zdrowie. }\end{array}$ \\
\hline
\end{tabular}

AF - aktywność fizyczna

W zastosowanym kwestionariuszu, stopniom realizacji poszczególnych potrzeb zdrowotnych przyporządkowane zostały wartości liczbowe $(0-$ brak potrzeby, 1 - w minimalnym stopniu, 2 - w dość dużym stopniu, 3 - w dużym stopniu, 4 - w największym stopniu), przy czym 4 (w największym stopniu) można było wybrać tylko raz.

Analizę statystyczną przeprowadzono z wykorzystaniem oprogramowania komputerowego Statistica v. 10.0 (StatSoft, Polska). Uzyskane wyniki przedstawiono $\mathrm{w}$ postaci wartości procentowych i średnich arytmetycznych, co było możliwe dzięki zastosowaniu skali ilościowej.

\section{Wyniki}

Spośród analizowanych potrzeb zdrowotnych, realizowanych wśród badanych seniorów przez podejmowaną aktywność fizyczną, najliczniejsza grupa badanych wskazała potrzeby prorodzinne $(92,3 \%)$, profilaktyczne $(91,9 \%)$, ruchu $(89,1 \%)$ oraz antyinwolucyjne i aktywności turystycznej (po 88,7\%). Najmniej liczna grupa zadeklarowała realizację potrzeby aktywnej niepełnosprawności $(69,2 \%)$ oraz rehabilitacyjnej (77,8\%) (Ryc. 1).

Badani deklarowali również stopień realizacji poszczególnych potrzeb zdrowotnych. Spośród tych, które realizowane były w dość dużym, dużym oraz największym stopniu, również dominowały potrzeby prorodzinne $(75,1 \%)$ i profilaktyczne $(75,1 \%)$; $\mathrm{w}$ dalszej kolejności uplasowały się potrzeby ruchu i rewitalizacji (po 67,0\%), funkcjonalno-czynnościowe $(65,2 \%)$ oraz antyinwolucyjne $(64,3 \%)$. Tymi, których realizacja najrzadziej deklarowana była w stopniu dość dużym, dużym i największym, okazały się potrzeby aktywnej niepełnosprawności $(49,3 \%)$ oraz rekreacji ruchowej $(54,8 \%)$. 


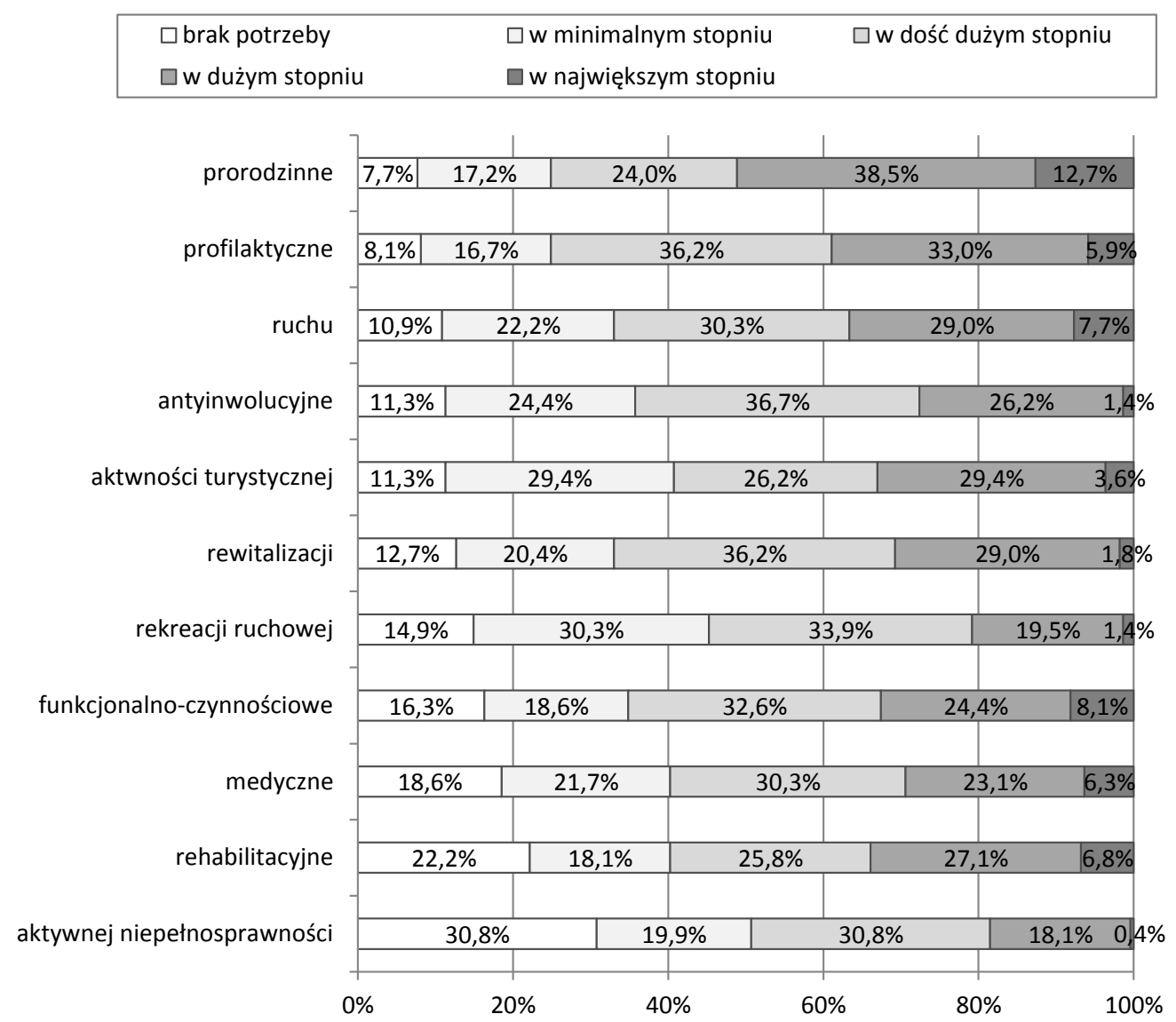

Rycina 1. Rodzaje potrzeb zdrowotnych badanych zaspokajanych przez podejmowaną aktywność fizyczną z uwzględnieniem stopnia ich realizacji (\%)

Respondenci mogli wskazać tylko jedną potrzebę zdrowotną, którą realizują w największym stopniu. Najliczniejsza grupa badanych wskazała potrzeby prorodzinne $(12,7 \%)$, w dalszej kolejności funkcjonalno-czynnościowe $(8,1 \%)$ oraz potrzebę ruchu $(7,7 \%)$. Najmniej liczna grupa zadeklarowała, iż (w największym stopniu) są to potrzeby aktywnej niepełnosprawności $(0,4 \%)$, antyinwolucyje $(1,4 \%)$, rekreacji ruchowej $(1,4 \%)$ oraz rewitalizacji $(1,8 \%)$.

Zastosowanie skali ilościowej umożliwiło wyliczenie średnich arytmetycznych, odzwierciedlających stopien realizacji analizowanych potrzeb zdrowotnych. Uzyskane wartości zilustrowano na ryc. 2.

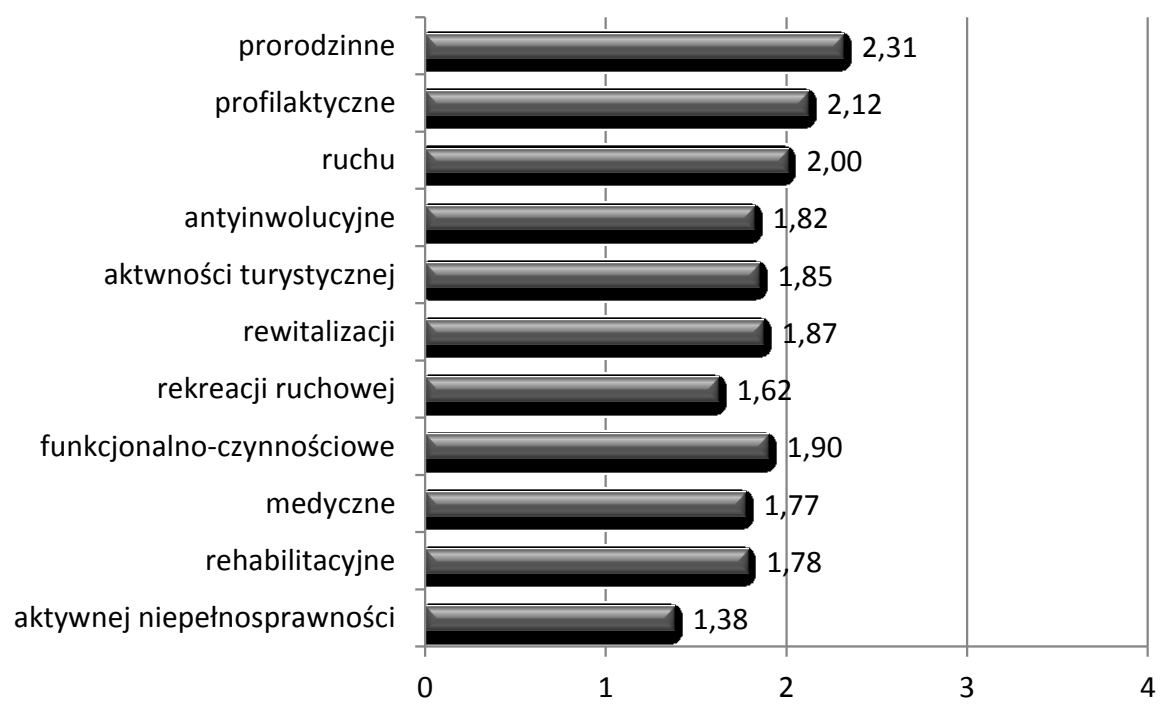

Rycina 2. Stopień realizacji potrzeb zdrowotnych poprzez podejmowaną przez badanych aktywność fizyczną (dane w postaci średnich arytmetycznych) 
Biorąc pod uwagę wyliczone średnie arytmetyczne, na pierwszym miejscu uplasowała się potrzeba prorodzinna $(\bar{x}=2,31)$. Na kolejnych miejscach znalazły się potrzeby profilaktyczne $(\bar{x}=2,12)$ i ruchu $(\bar{x}$ $=2,00)$. Najniższą średnią wartość uzyskała potrzeba aktywnej niepełnosprawności $(\bar{x}=1,38)$, minimalnie wyższą potrzeba rekreacji ruchowej $(\bar{x}=1,62)$, następnie potrzeby medyczne $(\bar{x}=1,77)$ i rehabilitacyjne $(\bar{x}=1,78)$.

\section{Dyskusja}

Spośród analizowanych potrzeb zdrowotnych, realizowanych wśród badanych seniorów przez podejmowaną aktywność fizyczną, na pierwszym miejscu uplasowały sie potrzeby prorodzinne. Potrzeby te minimalizują izolację i samotność osób starszych. Według badań Koprowiak i Nowak (2007), emeryci w większości przeznaczają czas wolny na pomoc w codziennych obowiązkach dzieciom i wnukom, na uprawianie działki, oglądanie telewizji, słuchanie radia, czytanie książek. Zdaniem Bień (2007) brak aktywności może powodować samotność, izolację społeczną, postępującą niesprawność, a nawet przedwczesną umieralność.

Potrzeby profilaktyczne okazały się drugimi w kolejności potrzebami zdrowotnymi realizowanymi przez badanych seniorów. Podejmowanie wysiłku fizycznego jako realizacja potrzeby profilaktycznej obejmuje zapobieganie wielu schorzeniom i chorobom. Potrzebę tę w procesie starzenia eksponuje wielu badaczy. Osiński (2013) ujął ją jako główny obszar oddziaływania aktywności fizycznej w skutecznym zapobieganiu chorobom układu krążenia, będących główną przyczyną przedwczesnej niepełnosprawności i zgonów. Niewystarczający poziom aktywności fizycznej to czynnik ryzyka miażdżycy, udaru, zapalenia stawów, cukrzycy, otyłości, osteoporozy i niektórych nowotworów. Regularny trening fizyczny seniorów, zdaniem Marchewki i in., poprawia funkcjonowanie układu sercowo-naczyniowego, przeciwdziała niekorzystnym zmianom chorobowym w układzie ruchu (sarkopenia, osteoporoza), pomaga ustabilizować takie choroby i schorzenia jak: cukrzyca, nadciśnienie, miażdżyca, choroba wieńcowa, a także stres czy otyłość (Marchewka, Dąbrowski, Żołądź, 2013). Badania Prączko i Kostki (2005) wykazały, że u osób w starszym wieku wraz ze wzrostem poziomu aktywności ruchowej może się zmniejszać liczba epizodów i dni z objawami występowania infekcji górnych dróg oddechowych.

Po potrzebach prorodzinnych i profilaktycznych uplasowały się potrzeby ruchu, funkcjonalno-czynnościowe i rewitalizacji. Potrzeba ruchu to praktykowanie zdrowego stylu życia, oparte na wiedzy i wcześniejszych doświadczeniach. Z kolei potrzeba rewitalizacji to aktywność fizyczna zwiększająca żywotność ustroju, usprawniająca procesy życiowe, dodająca życia do lat, jak to określił i zaprezentował na własnym przykładzie znany szwedzki fizjolog P.O. Astrand (za Drygas, Jegier, 2003). Obydwie potrzeby są realizowane przez dobrowolne uczestniczenie w aktywności fizycznej dające poczucie wartości i poprawiające jakość życia. Takie zachowania pozwalają realizować proces pomyślnego starzenia się, który zdaniem Błędowskiego i in. (2012) dotyczy coraz większej grupy seniorów (Kozdroń, 2014; Wieczorkowska-Tobis, Talarska, 2010). Według badań GUS, potrzeba funkcjonalno-czynnościowa u co trzeciej starszej osoby jest ograniczona, co utrudnia wykonywanie codziennych czynności związanych z samoobsługą (GUS, 2014).

Wśród badanych seniorów w najmniejszym stopniu realizowana była potrzeba aktywnej niepełnosprawności. Oszacowano, że w ciągu dwudziestu lat $w$ populacji polskiej zmalał odsetek osób starszych niesprawnych fizycznie (Rowiński, Dąbrowski, 2012). Według raportu Czapińskiego i Błędowskiego (2014), wśród polskiego społeczeństwa w wieku 60-74 lat, osób ze znaczną niepełnosprawnością jest około 5,0\%, a w grupie 80-latków i starszych 20,0\% i powyżej. Według Klukowskiego (2012), w kinezyterapii ogólnoustrojowej osób z niepełnosprawnością wykonywane są wysiłki tlenowe, beztlenowe i mieszane, które wywołują wiele doraźnych jak i długofalowych zmian. Jeżeli są regularne i intensywne zwiększają zdolności przystosowawcze organizmu do pracy fizycznej. Osoba z niepełnosprawnością zwiększa tak tolerancję na zmęczenie, co pozwala wykonywać czynności codzienne w większym komforcie psychofizycznym.

Wśród badanych seniorów niewielki stopień realizacji dotyczy również potrzeby rekreacji ruchowej, co może wskazywać na brak znajomości i doceniania jej efektów zdrowotnych. Podejmowanie rekreacyjnej aktywności ruchowej z nawyku w badaniach Pol Senior deklarował zaledwie co szósty badany (17,5\%) (Rowiński, Dąbrowski, 2012).

\section{Wnioski}

Badani seniorzy, przez aktywność fizyczna, realizowali wszystkie analizowane potrzeby zdrowotne. Najliczniejsza grupa realizowała potrzeby prorodzinne, profilaktyczne, ruchu, antyinwolucyjne oraz aktywności turystycznej. W największym stopniu zaspokajane były potrzeby prorodzinne, profilaktyczne oraz ruchu, natomiast $w$ najmniejszym potrzeby aktywnej niepełnosprawności i rekreacji ruchowej.

\section{Podziękowania}

Autorki składaja podziękowania Adamowi Szepelukowi z Centrum Badań nad Innowacjami Państwowej Szkoły Wyższej im. Papieża Jana Pawła II w Białej Podlaskiej, za wykonanie obliczeń statystycznych wykorzystanych w artykule. 


\section{Literatura:}

1. Ainsworth, B.E., Jacobs D.R., Leon A.S. (1993). Validity and reliability of self-reported physical activity status: the Lipid Research Clinics questionnaire. Medicine and Science in Sport and Exercise, 25(1), 92-98. https://doi.org/10.1249/00005768-199301000-00013

2. Bień, B. (2007). Proces starzenia się człowieka. W: T. Grodzicki, J. Kocemba, A. Skalska (red.), Geriatria z elementami gerontologii ogólnej (s. 42-46). Gdańsk: Via Medica.

3. Błędowski, P., Szatur-Jaworska, B., Szweda-Lewandowska, Z., Kubicki, P. (2012). Raport na temat sytuacji osób starszych w Polsce. Instytut Pracy i Spraw Socjalnych, Warszawa. Pobrane z: http://senior.gov.pl/ source/raport_osoby\%20starsze.pdf

4. Czapiński, J., Błędowski, P. (2014). Aktywność społeczna osób starszych w kontekście percepcji Polaków. Diagnoza społeczna 2013. Ministerstwo Pracy i Polityki Społecznej i Centrum Rozwoju Zasobów Ludzkich, Warszawa. Pobrane z: http://www.diagnoza.com/pliki/raporty_tematyczne/Aktywnosc_spoleczna_osob_starszych.pdf.

5. Drabik, J., Resiak, M. (red.). (2010). Styl życia w promocji zdrowia. Gdańsk: Wyd. AWFiS.

6. Drygas, W., Jegier, A. (2003). Zalecenia dotyczące aktywności ruchowej w profilaktyce układu krążenia. W: M. Naruszewicz (red.), Kardiologia zapobiegawcza (s. 252-266). Szczecin: PTBnM Verso.

7. Drygas, W., Piotrowicz, R., Jegier, A., Kopeć, G., Podolec, P. (2010). Aktywność fizyczna u osób zdrowych. W: P. Podolec (red.), Podręcznik Polskiego Forum Profilaktyki. T.2 (s. 437-442). Kraków: Wyd. Medycyna Praktyczna.

8. Florek-Łuszczki, M., Lachowski, S., Kowalczyk-Bołtuć, J., Dziemidok, P., Jaworska, J., Tochman-Gawda, A., Szcześniak, G., Paprzycki, P., Janowska, A., Cisak, E., Wójcik-Fatla, A., Zając, V., Sawczyn, A., Kloc, A., Sroka, J., Dutkiewicz, J., Saran, T., Maruszewska, A., Bojar, I. (2015). Ocena stanu zdrowia oraz określenie potrzeb zdrowotnych mieszkańców województwa lubelskiego na potrzeby opracowywania programów polityki zdrowotnej realizowanych przez Samorzą Województwa Lubelskiego w latach 2016-2021. Urząd Marszałkowski Województwa Lubelskiego, Lublin. Pobrane z: http://prawomiejscowe.pl/FILE_REPOSITORY/17065/LegalActs/161059/Zalacznik1.pdf.

9. Gajos, A., Kujawski, S., Gajos, M., Chatys, Ż., Bogacki, P., Ciesielska, N., Zukow, W. (2014). Effect of physical activity on cognitive functions in elderly. Journal of Health Sciences, 4(8), 91-100. Pobrane z: http://citeseerx.ist.psu.edu/viewdoc/download?doi=10.1.1.673.190\&rep=rep1\&type=pdf.

10. Grzanka-Tykwińska, A., Kędziora-Kornatowska, K. (2010). Aktywności osób w podeszłym wieku. Gerontologia Polska, 18(1), 29-32.

11. GUS (2014). Sytuacja demograficzna osób starszych i konsekwencje starzenia się ludności Polski w świetle prognozy na lata 2014-2050. Pobrane z: http://www.wspolnota.org.pl/uploads/tx_news/ludnosc_w_ starszym_wieku.pdf.

12. Ignasiak, Z., Skrzek, A., Sławińska, T., Rożek-Piechura, K., Steciwko, A., Domaradzki, J., Fugiel, J., Posłuszny, P. (2011). Wstępna ocena kondycji biologicznej wrocławskich seniorek. Gerontologia Polska, 19(2), 91-98.

13. Jegier, A., Stasiołek, D. (2001). Skuteczna dawka aktywności fizycznej w prewencji pierwotnej chorób układu krążenia i promocji zdrowia. Medicina Sportiva, 5, suppl. 2, 109-118.

14. Klukowski, K. (2012). Wysiłek i sport osób niepełnosprawnych. W: J. Górski (red.), Fizjologia wysiłku i treningu fizycznego (s. 198-241). Warszawa: Wyd. Lekarskie PZWL.

15. Koprowiak, E., Nowak, B. (2007). Style życia ludzi starszych. Annales Universitatis Mariae Curie-Skłodowska. Wydawnictwo Neuro-Centrum, Lublin.

16. Kostka, T. (2010). Aktywność fizyczna u osób w podeszłym wieku. W: P. Podolec (red.), Podręcznik Polskiego Forum Profilaktyki. T.2 (s. 455-460). Kraków: Wyd. Medycyna Praktyczna.

17. Kozdroń, E. (2012). Kultura fizyczna-sport dla wszystkich. W: Rzecznik Praw obywatelskich, Strategia działania w starzejacym się społeczeństwie. Tezy i rekomendacje (s. 63-72). Warszawa. Pobrane z: https:// www.rpo.gov.pl/pliki/13541772380.pdf.

18. Kozdroń, E. (2014). Aktywność rekreacyjna w procesie pomyślnego starzenia się. Zeszyty Naukowe WSKFiT, 9, 75-84.

19. Lampinen, P., Heikkinen, R.L., Kauppinen, M., Heikkinen, E. (2006). Activity as a predictor of mental well-being among older adults. Aging \& Mental Health, 10(5), 454-466. https://doi.org/10.1080/13607860600640962

20. Leveille, S.G., Guralnik, J.M., Ferrucci, L., Langiois, J.A. (1999). Aging successfully until death in old age: opportunities for increasing active life expectancy. Am. J. Epidemiol., 149(7), 654-664. https://doi.org/10.1093/oxfordjournals.aje.a009866

21. Majchrowska, A. (2003). Zachowania zdrowotne-aspekty socjologiczne. W: A. Majchrowska (red.), Wybrane elementy socjologii (s. 293-316). Lublin: Wyd. Czelej.

22. Makuła, W. (2012). Usprawnianie ruchowe seniorów. Wybrane zagadnienia profilaktyki gerontologii. Nowy Sącz: PWSZ w Nowym Sączu.

23. Marchewka, A., Dąbrowski, Z., Żołądź, J.A. (red.). (2013). Fizjologia starzenia się. Profilaktyka i rehabilitacja. Warszawa: Wyd. Naukowe PWN. 
24. Ministerstwo Pracy i Polityki Społecznej (2013). Europejski Rok Aktywności Osób Starszych i Solidarności Międzypokoleniowej 2012 w Polsce. Raport ewaluacyjny. Warszawa. Pobrane z: http://senior.gov.pl/assets/uploads/Załącznik nr 12.pdf.

25. Mossakowska, M., Więcek, A., Błędowski, P. (red.). (2012). Aspekty medyczne, psychologiczne, socjologiczne i ekonomiczne starzenia się ludzi w Polsce. Poznań: Termedia Wyd. Medyczne. Pobrane z: http://212.87.21.2/ polsenior/sites/polsenior.iimcb.gov.pl/files/file/monografia/monografiaPolSenior.pdf.

26. Osiński, W. (2013). Gerokinezjologia. Nauka i praktyka aktywności fizycznej w wieku starszym. Warszawa: Wyd. Lekarskie PZWL.

27. Pedersen, B. K., Hoffman-Goetz, L. (2000). Exercise and the immune system: regulation, integration, and adaptation. Physiol Rev. 80(3), 1055-1081. https://doi.org/10.1152/physrev.2000.80.3.1055

28. Prączko, K., Kostka, T. (2005). Aktywność ruchowa a infekcje. Gerontologia Polska, 13(3), 195-199.

29. Rottermund, J., Knapik, A., Szyszka, M. (2015). Aktywność fizyczna a jakość życia osób starszych. Społeczeństwo i Rodzina, 42(1), 78-98.

30. Rowiński, R., Dąbrowski, A. (2012). Aktywność fizyczna Polaków w wieku podeszłym. W: M. Mossakowska, A. Więcek, P. Błędowski (red.), PolSenior Aspekty medyczne, psychologiczne, socjologiczne i ekonomiczne starzenia się ludzi w Polsce (s. 531-548). Poznań: Termedia Wyd. Medyczne. Pobrane z: http://212.87.21.2/ polsenior/sites/polsenior.iimcb.gov.pl/files/file/monografia/monografiaPolSenior.pdf.

31. Słopiecka, A., Cieślik, A. (2011). Zachowania zdrowotne - wybrane definicje. Studia Medyczne, 24(4), 77-81.

32. Suchecka, J. (2010). Ekonomia zdrowia i opieki zdrowotnej. Warszawa: Wyd. Wolters Kluwer.

33. Syrek, E. (2000). Zdrowie w aspekcie pedagogiki społecznej. Katowice: Wyd. Uniwersytetu Śląskiego.

34. Terra Sílvia, R., Gonçalves da Silva, A., Salerno Pinto, V., Lourenço Dutra, P.M. (2012). Effect of exercise on the immune system: Response, adaptation and cell signaling. Rev Bras Med Esporte, 18(3), 208-214.

35. Topór-Mądry, R., Gilis-Januszewska, A., Kurkiewicz, J., Pająk, A. (2002). Szacowanie potrzeb zdrowotnych. Kraków: Wyd. Vesalius.

36. Wieczorkowska-Tobis, K., Kostka, T., Borowicz, A.M. (red.). (2011). Fizjoterapia w geriatrii. Warszawa: Wyd. Lekarskie PZWL.

37. Wieczorkowska-Tobis, K., Talarska, D. (red.). (2010). Pozytywna starość. Poznań: Uniwersytet Medyczny.

38. Woynarowska, B. (2008). Edukacja prozdrowotna. Warszawa: PWN.

39. Zarzeczna-Baran, M. (2010). Potrzeby zdrowotne. Baza programów zdrowotnych województwa pomorskiego. Pobrano z: http://bazaprogramow.zdrowiedlapomorzan.pl/ public_html/upload/Potrzeby\%20 zdrowotne.pdf.

40. Zdziarski, M. (2015). Seniorze, trzymaj formę! Aktywność fizyczna osób starszych. Kraków: Ministerstwo Sportu i Turystyki. Inst. Łukasiewicza.

41. Żołnierczuk-Kieliszek, D. (2014). Zachowania zdrowotne i ich związek ze zdrowiem. W: T.B. Kulik, A. Pacian (red.), Zdrowie publiczne (s. 64-85). Warszawa: Wyd. Lekarskie PZWL. 